\title{
Repositioning An Academic Department To Stimulate Growth
}

Cassandra C. Elrod, Ph.D., Missouri University of Science \& Technology, USA

William J. Daughton, Ph.D., Missouri University of Science and Technology, USA

Susan L. Murray, Ph.D., Missouri University of Science and Technology, USA

Caroline M. Fisher, Ph.D., Missouri University of Science \& Technology, USA

Barry B. Flachsbart, Ph.D., Missouri University of Science \& Technology, USA

\begin{abstract}
The complexity of the market in higher education, and the lack of literature regarding marketing, particularly branding, at the academic department level, presented an opportunity to establish a systematic process for evaluating an academic department's brand meaning. A process for evaluating a brand's meaning for an academic department is developed in this paper using Keller's Customer Base Brand Equity model. This process will aid academic departments experiencing perception problems or wishing to improve their brand to better understand their existing brand meaning and assess the alignment between the student market perception and the industry market perception. This systematic process for evaluating a brand's meaning is presented as applied to a case study.
\end{abstract}

Keywords: repositioning; growth; brand; brand meaning; academia; Keller; academic department

\section{INTRODUCTION}

2 review of the existing literature indicates that little study has been made of branding academic departments below the university level. The lack of intentional branding leaves to chance the perceptions that potential students and future employers of these students have about an academic unit. The impact may be most significant for units where the fields of study that are represented by the department are relatively new. However, even in the cases of better-understood fields of study, the competition with other fields or universities for students may drive a need for better branding.

Focusing branding at a department level becomes even more challenging than at the university level, due to the smaller size of the entity being branded. Much of a department's brand identity comes from the name and ranking of the department. Since there are no universal ranking criteria, some research suggests mathematical ways to rank schools and some use methods that are more subjective. Burch and Nanda used the Hotelling model and its assumption of risk neutrality. The mathematical equation of the model was applied to the process of naming business schools; such schools received more money when the naming of the school was delayed. The general conclusion was that while business schools can somewhat control the dollar amount of their naming gifts, it is much more difficult to control more intangible resources such as perceived brand quality (Burch \& Nanda, 2005).

A process for evaluating an academic department brand's meaning is presented in this study. The model provides a way to identify and catalogue brand meaning, and to locate the understanding of the brand in a hierarchy of branding elements using Keller's Customer Base Brand Equity model across various stakeholder groups (Keller, 2001; Keller, 2003). These outcomes provide a path for brand improvement in the minds of future students and employers of graduates of an academic department. 


\section{BACKGROUND AND SUPPORTING LITERATURE}

A brand is often thought of a name, term, sign, symbol, or design, or a combination of the aforementioned, intended to identify the goods and services of one seller or group of sellers and to differentiate them from those of competition (Keller, 2003). Simply put, a brand is a trust mark, a warrant, and a promise (Seiver, 2001). In a practical sense, the term brand refers to more than just a name, term, sign, symbol, or design. Many practicing managers use the term brand to refer to awareness, reputation, prominence, and so on in a marketplace. The true brand is a common perception about a deliverable that is assigned by the brand's market. Ultimately, a brand is something that resides in the minds of consumers (Keller, 2003).

Branding is important because it is the perception, or general notion, that people have about a good or service. A brand can be a physical good, a service, a store, a person, a place, an organization, or an idea and can create competitive advantages Typically, consumers will have multiple associations to a strong brand. By developing a strong brand that differentiates a product or service from its competition, marketers create value in the brand that translates into profits. Often, the most valuable asset to a company or organization is an intangible asset such as marketing, keen financial planning or management skills, and ultimately the brands themselves (Keller, 2003).

Marketing in Higher Education. Marketing's appropriateness for higher education has been debated in the literature throughout the last century (Hemsley-Brown \& Oplatka, 2006). In higher education, some argue that the market is prospective students while others argue that the future employers of graduates are the customers of higher education (Franzak, 1993). Some research claims that brand messages conveyed in marketing have multiple groups of importance; the argument is that the marketing message illustrated to employees of an organization is equally as important to the brand message sent to external stakeholders (Judson, Gorchels, \& Aurand, 2006). For this study, the market segments were two-fold: prospective students and future employers of the graduates of a higher education program (Conway, 1994).

These two market segments depend on each other for existence; students enrol in higher education programs with the expectation that employers will hire them, and employers look to higher education institutions to provide them with graduates to employ (Franzak, 1993). Since there is a strong bond between these two existing markets, their perceptions, or brand meanings, of a higher education department's "brand" must be aligned to ensure that the above-mentioned process functions properly.

Branding has become a basic tool of marketing (Leitch, 2005) and is one aspect of marketing for a product or service (Keller, 2003), It applies to higher education in the sense that a university, for example, is making a "promise" to prospective students about what their academic departments have to offer and to industry regarding the calibre of graduates that they will provide to the employment pool. Because universities are by definition very diverse, channelling the complexity into a simple, compelling brand concept is challenging (Bodoh, 2004). The literature regarding marketing of higher education identifies the need for branding and for institutions developing a good brand at the overall university level, but a significant gap exists in the literature regarding this process at the academic departmental level (University of Saskatchewan, 2007; Judson, et. al, 2006; Heist, 2007; Colyer, 2005; Leitch, 2005; The University of Hawaii System, 2002; Missouri University of Science \& Technology, 2007; Young, 2007; University of New Hampshire, 2007). Universities are more visible than academic departments due to sheer size.

Currently, universities and institutions of higher education are focusing on branding techniques to enhance their visibility and attract more attendees (University of Saskatchewan, 2007; Judson, et. al, 2006; Heist, 2007; Colyer, 2005; Leitch, 2005; The University of Hawaii System, 2002; Missouri University of Science \& Technology, 2007; Young, 2007; University of New Hampshire, 2007). Despite having a very strong brand image among engineers world-wide, the University of Missouri - Rolla changed its name to the Missouri University of Science and Technology in January of 2008, and is in the process of rebranding itself to the new name. The university implemented these efforts to increase awareness both nationally and internationally, that the university is centred on science and technology based programs, and isn't just a branch of the University of Missouri-Columbia (Missouri University of Science \& Technology, 2007). This will also help the university compete and meet its strategic vision 
of becoming one of the "top five technological universities." The literature is scarce regarding university efforts to understand brand meaning to improve alignment between the student and industrial markets and ensure a smooth, cyclical process from one to another.

Rationale for the Study. The complexity of the market in higher education, and the lack of literature regarding marketing, particularly branding, at the academic department level, presented an opportunity to establish a systematic process for evaluating an academic department's brand meaning. This process will aid academic departments experiencing a perception problem, or those that simply wish to improve their brand, to better understand their existing brand meaning to their markets and to align the student market perception to the industry market perception. This process may also prove useful to universities in general or to other organizations suffering from perception problems wishing to ensure alignment of their market perceptions. The process could have been applied to a full university but a department was chosen because it recognized that it had a perception (branding) problem both internal and external to the university.

The Customer Based Brand Equity Model. Brand equity is one of the most interesting topics among both academic researchers and marketing practitioners (Woods, 2000; Quan, 2006). The following discussion regarding the customer based brand equity model and its implications were derived and published by Kevin Keller (Keller, 2001; Keller, 2003). Applications of Keller's Customer Based Brand Equity model appear in the literature in contexts such as business-to-business scenarios and evaluating customer based restaurant brand equity (Kuhn, Retrieved 2007; Kim, 2004, Kuhn, 2008). Keller's ideas were used regarding brand equity, as his work on brand equity is widely used in the literature (Keller, 2001; Keller, 2003, Kuhn, Retrieved 2007; Kim, 2004, Kuhn, 2008, James, 2006; Kayaman \& Arasli, 2006; Tong \& Hawley, 2009; Jung \& Sung, 2008).

Developing a brand is important, but developing a brand that accurately reflects the organization's deliverable is even more important. Often companies have trouble initiating the branding process because of the large number of different brands in a single category. Keller developed the customer based brand equity model (CBBE) to help answer common questions such as "What makes a brand strong?" and "How do organizations build strong brands?" The following discussion outlines components of the CBBE model and follows a hierarchy in the process of strong brand building as outlined in Figure 1 below.

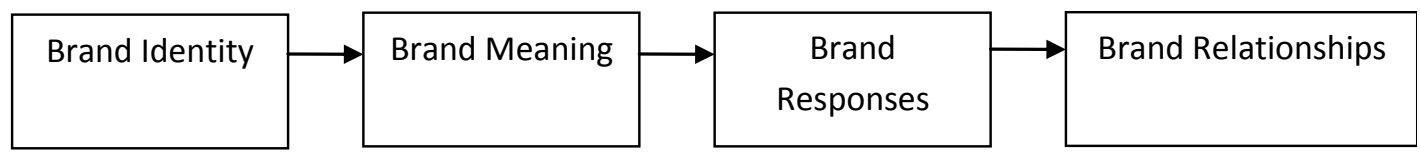

Figure 1: Keller's Strong Brand Building Hierarchy (Keller, 2001; Keller, 2003)

Brand Identity. Brand identity answers the general question of "who are you?" for customers and is the art of creating proper brand awareness. It refers to the customer's ability to recognize or recall a brand under various situations or circumstances. Overall, brand awareness focuses on ensuring that a customer knows what "needs" a particular brand will satisfy or what basic functions the brand serves for the customer (Keller, 2001; Keller, 2003).

Brand Meaning. Ensuring that a brand has the desired meaning to its customers is very important. Brand meaning should create an image in the customer's minds about what the brand stands for and is characterized by. In general, it can be distinguished in terms of more functional "performance" based factors versus more abstract "image" related factors. These brand meanings can be formed directly by a customer's experiences and/or contact with a brand via advertising, marketing efforts, or other sources of information (Keller, 2001; Keller, 2003). Brand meaning answers the general question of "what are you?" to customers.

Brand Responses. Brand response focuses attention on how customers react to a brand. Typically, these reactions follow brand meaning and address the question of "what do I think or feel about you?" Generally, brand responses are classified as either a "judgment" or a "feeling" (Keller, 2001; Keller, 2003). 
Brand Relationships. The last step in building a strong brand focuses on the relationships or how much of a personal identification a customer has with a particular brand. This addresses the customer's question of "what kind of an association and how much of a connection would I like to have with you?" This phenomenon is called brand "resonance" (Keller, 2001; Keller, 2003).

The above model reinforces that strong brand meaning cannot be established unless an identity is first created. Responses to a brand cannot be created until a meaning has been placed on the brand; and finally a relationship cannot be established without getting proper responses from a brand's customers (Keller, 2001; Keller, 2003).

Six Building Factors of the CBBE Model. Keller breaks down his four questions to build a strong brand into six foundation factors with the brand's customers: salience, performance, imagery, judgments, feelings, and resonance, and then further identifies sub-dimensions of the six factors (Keller, 2001; Keller, 2003). Figure 2 outlines the relationships between the four questions that customers generally ask when relating to a strong brand, the six factors of the foundation of a strong brand and their sub-dimensions, and the discussion of each follows.

\begin{tabular}{|c|c|l|}
\hline Four Questions Of CBBE & Six Factors Of CBBE Model & \multicolumn{1}{|c|}{ Sub-Dimensions Of Six Factors } \\
\hline Brand Identity & Salience & Category Identification; Needs Satisfied \\
\hline \multirow{2}{*}{ Brand Meaning } & Performance & $\begin{array}{l}\text { Primary characteristics \& secondary features; Product } \\
\text { reliability, durability \& serviceability; Service } \\
\text { effectiveness, efficiency \& empathy; Style \& design; } \\
\text { Price }\end{array}$ \\
\cline { 2 - 3 } & Imagery & $\begin{array}{l}\text { User profiles; purchase \& usage situations; } \\
\text { Personality \& values; History, heritage, \& experiences }\end{array}$ \\
\hline \multirow{2}{*}{ Brand Response } & Judgments & Quality; Credibility; Consideration; Superiority \\
\cline { 2 - 3 } & Feelings & $\begin{array}{l}\text { Warmth; Fun; Excitement; Security; Social approval; } \\
\text { Self-respect }\end{array}$ \\
\hline Brand Relationships & Resonance & Loyalty; Attachment; Community; Engagement \\
\hline
\end{tabular}

Figure 2: CBBE Summary (Keller, 2001)

Brand Salience. Brand salience relates different aspects of brand awareness, for example, how often or how easily a brand comes to mind in numerous situations or circumstances.

Brand Performance. The way that a product or service attempts to meet its customers' functional needs is called performance. This aspect includes intrinsic properties of the brand, product or service characteristics.

Brand Imagery. Creating a brand image that reflects how a brand is characterized and what it should stand for in a customer's mind is important when trying to give a brand meaning. Imagery explains the extrinsic properties of a product or service, such as how the brand attempts to meet more psychological or social needs of the customer.

Brand Judgments. An integral part of establishing a strong brand is paying attention to how the customers respond to the brand. Typically, these responses are classified as either judgments or feelings. Judgments are a customer's opinion or beliefs about a brand that are based on the way the individual assembles different performance and imagery associations.

Brand Feelings. Feelings are a customer's emotional reaction to a brand. Six types of feelings are associated with a strong brand: 1) warmth, 2) fun, 3) excitement, 4) security, 5) social approval, and 6) self-respect.

Brand Resonance. The final step to building a strong brand in the CBBE model revolves around the level of personal identification that a customer has with a brand. The nature of the relationship that a customer has with a brand and how much the customer can personally identify with the brand refers to brand resonance. It is gauged by the amount of psychological attachment a customer has with the brand and how much activity that attachment renders. 
CBBE Model Implications. The strongest brands excel at all six of the factors of the CBBE Model (Keller, 2001; Keller, 2003). According to Keller's CBBE model, brand resonance is the most valuable factor of the model as successful brand resonance ensures that customers are thinking of the brand, have good feelings about the brand, and ultimately are buying and using the brand (Keller, 2001; Keller, 2003). Successful brand resonance implies successful implementation and harmonious synchronizing of all other factors of the model, as strong brand building must achieve all other factors and levels of the model before reaching brand resonance, at the pinnacle of the model (See Figure 3). Academic departments that are building their brand need to start at the bottom of the branding pyramid, at Brand Identity (Salience), and work upwards to ensure they build the strongest brand possible. The type of symptoms $r$ academic departments are experiencing determines where in the branding model they need to start their evaluation. This paper reflects academic departments initiating the evaluation process at the brand meaning level (Performance and Imagery), as many departments are identifiable at the brand identity stage (i.e. business, engineering, humanities, etc.) Ultimately, using the CBBE model in sequence will help brands achieve strong brand resonance, loyal customers, and greater, more effective marketing programs (Keller, 2001; Keller, 2003).

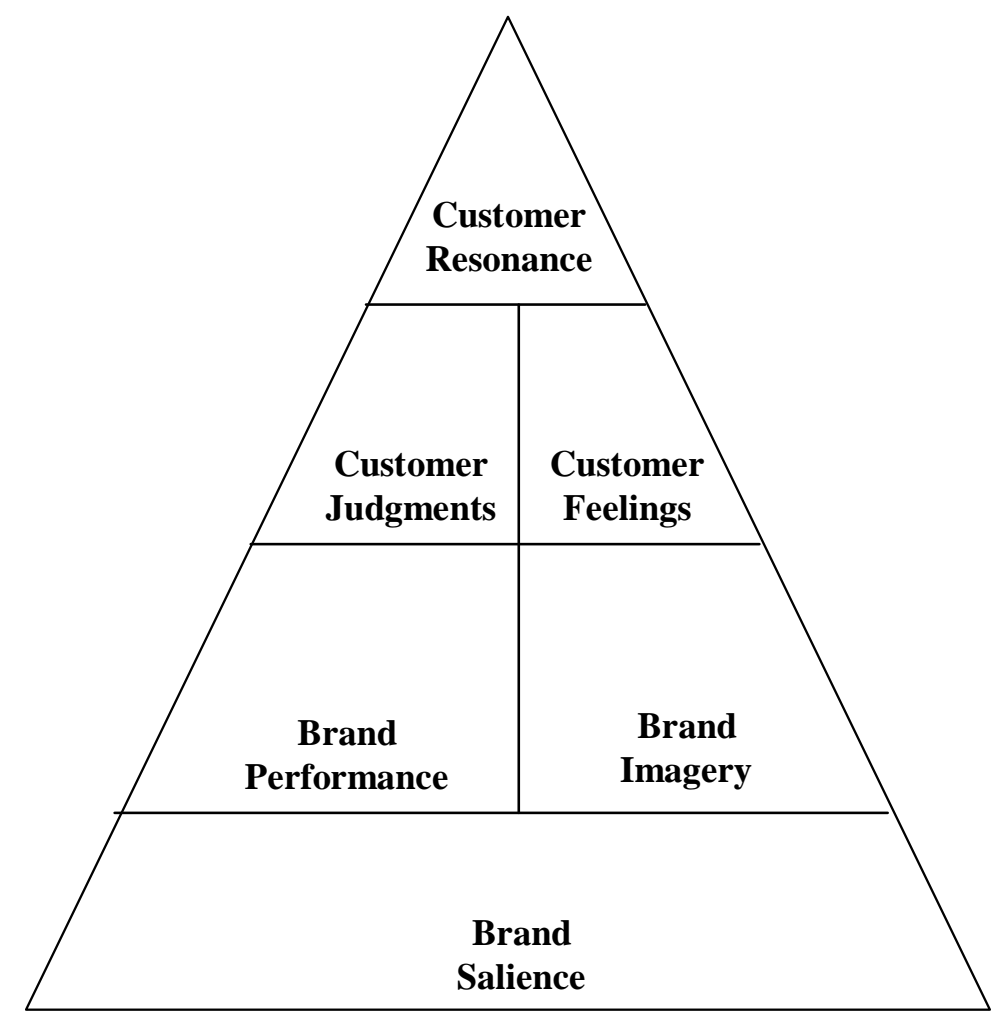

Figure 3: Customer Based Brand Equity Ideal Pyramid (Keller, 2001)

The Need for Branding an Academic Department. The limited research on branding universities, schools, and departments states that business schools are focused on branding their reputation even more so than their parent universities. However, there is little effort in implementation and in-house resources are lacking to put this idea into action effectively. (Argenti, 2000). While there has been a recent explosion of ranking business schools, there is still little focus on branding. The validity of current ranking systems as a measure of reputation and image is questioned by organizations worldwide (Vidaver-Cohen, 2007). The reputation of any organization has various stakeholders. Different literature suggests different classifications of stakeholders and factors of importance to these stakeholders; one proposition is that reputation consists of two dimensions: stakeholder's perception of the goods and services and organizations' prominence in the stakeholder's mind (Petkova, Rindova, \& Williamson, 2005). A 
review of the literature does not reveal the notion of brand meaning and/or brand development at the academic department level, rather it finds academic branding efforts concentrated at the university or institution level (University of Saskatchewan, 2007; Judson, et. al, 2006; Heist, 2007; Colyer, 2005; Leitch, 2005; The University of Hawaii System, 2002; Missouri University of Science \& Technology, 2007; Young, 2007; University of New Hampshire, 2007). The researchers designed a systematic process to help academic departments suffering from poor perceptions and understanding of their academic departments or degree fields. The process will help speed the identification of underlying problems that an academic department may be having. A logical place to begin fixing a brand perception or understanding problem would be to study the problem at hand and determine the underlying cause.

\section{A SYSTEMATIC PROCESS FOR EVALUATING AN ACADEMIC BRAND}

In this paper, a systematic process to evaluating an academic department's brand meaning is described. The process developed in this paper uses the "word association" method of evaluating brand meaning (Kotler, 2003). The open ended format for responses to brand meaning affords the stakeholder the opportunity to submit unbiased, "knee jerk" reactions that will reflect what the brand means to that stakeholder when it is initially presented. Gathering these initial reactions from both students and potential employers will aid in determining whether the two markets are aligned in their brand understanding.

The goals of this process are (1) to investigate brand meaning of academic departments by stakeholder markets, (2) to determine if the stakeholder responses to brand meaning are appropriate, and (3) to determine if the stakeholders from more than one market share the same brand meaning for the same academic department, indicating alignment.

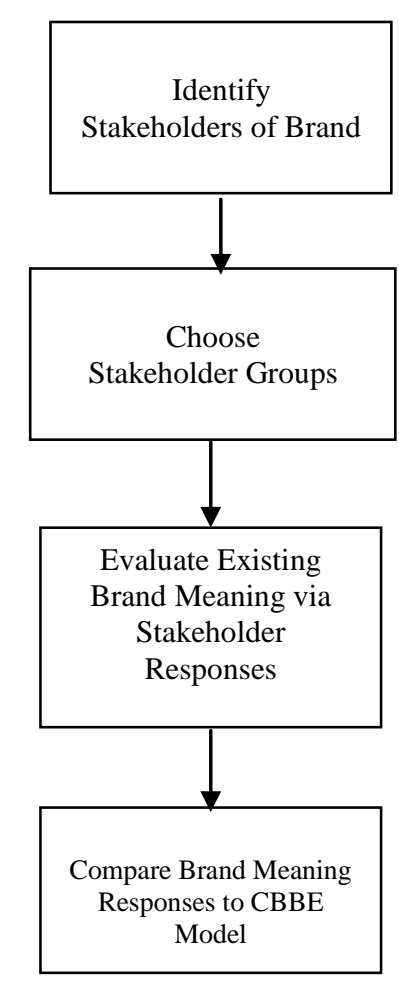

Figure 4: Systematic Process to Evaluating an Academic Brand (Elrod, 2007) 
Figure 4 depicts the steps in identifying underlying brand perceptions. It uses the CBBE model as the foundation for gathering data to analyze. This systematic process acquires knowledge about overall self-reported understanding of the academic department and the field of study by different stakeholder groups. Understanding of the broader field of study in which the academic department resides is compared with other academic departments within the overall field of study. For example, the engineering management academic department is one within the broad field of engineering, and other academic departments in this field are electrical engineering, civil engineering, and mechanical engineering.

Stakeholder Identification and Selection to Evaluate Brand Meaning. Before evaluating brand meaning, an academic department must first identify its stakeholders. In general, the literature describes academic stakeholders as being donors, industrial employers, alumni, prospective students, and current students. Other possible stakeholders are faculty, trustees, administrators, families of students, and journalists (Rossum, 2001). The academic department that wishes to implement this process must be sure to carefully identify the markets that it wishes to have evaluate its brand and its specific and general fields of study. If the department is accredited by the Accreditation Board for Engineering and Technology (ABET), their stakeholders have already been identified as part of the accreditation process.

All stakeholders can be evaluated as a comprehensive study, or two particular types of stakeholders can be evaluated and compared. For example, to evaluate the alignment of the student to the employer market, the department evaluates both prospective and current students and compares the results to those from existing or potential employers of those students. Ideally, both groups of stakeholders would hold the same brand meaning (Elrod, 2007; Elrod, et. al., 2010).

Evaluate Existing Brand Meaning. To establish a brand or evaluate the effectiveness of a branding campaign, Kotler (2003) mentions three commonly used research methods for uncovering brand meaning to customers. "Word association" is a common technique employed to evaluate customers' feelings, knowledge, motivations and brand meaning where researchers ask stakeholders what words come to mind when presented with the brand (Keller, 1993; Chandon, 2003; Keller, 2003; Kotler, 2003; Belk, 2006). Secondly, "personifying the brand" might include asking people to describe what kind of person or animal comes to mind when a brand is mentioned, or any question that will solicit a human aspect of the brand such as what type of people would use it. Finally, "laddering up to find the brand essence" relates to the deeper, more abstract goals consumers are trying to satisfy when they select a brand. Brand essence is what ultimately matters to the stakeholder, as it is the stakeholder's basis for choosing the brand.

Compare Academic Department Brand Meaning Responses to CBBE Model. In order to evaluate the brand meaning of an academic department using the "word association" method of brand meaning evaluation (Keller, 1993; Chandon, 2003; Keller, 2003; Kotler, 2003; Belk, 2003), the individual responses are coded into the six factors of the CBBE model. The researcher establishes a rubric for assigning responses to a factor in the CBBE model. These responses and assignments will vary for each academic department due to the nature of the fields of study they represent. The sub-dimensions of the six factors of the CBBE model, given in Figure 2, provide guidance for coding. For example, responses reflecting a "category identification" or some type of "need fulfilment" would fall into the "salience" factor and be coded consistently to that category. Stakeholder responses that are coded as Performance or Imagery factors that make up brand meaning in the CBBE model should be considered "appropriate" responses to brand meaning. Responses that fall into other categories of the CBBE model should be considered "inappropriate" responses to brand meaning and eliminated from further analysis of the brand meaning.

The aforementioned method of coding requires accuracy and judgment; care must be taken to place each response into the proper factor. Since this method requires the development of a rubric for coding, the researcher needs to recruit another person to code the data using the developed rubric to measure and ensure the reliability of the coding method. The goal of this method of establishing inter-rater reliability is to ensure that the rubric consistently returns the same results (Creswell, 2005) and that the coding is performed consistently. A Cohen's kappa is calculated to determine the confidence in the inter-rater reliability of the data coding between the researcher and research assistant. A Cohen's kappa value above 0.7 is considered to be a good inter-rater reliability (Scott, 
1955). After all responses are coded and the reliability of the coding is verified, the frequency of responses for each factor of the CBBE model is determined for each population.

Analysis of the responses to the "word association" question will show whether the stakeholders' brand meaning falls into the appropriate responses to brand meaning per the CBBE model (Keller, 2001). The brand meanings of the different stakeholder groups are compared to assess whether their responses are aligned in the factor of the CBBE model. If the responses are consistently coded into the "brand meaning" level of the CBBE model (Performance and Imagery factor categories) by all markets, then the brand meaning can be considered developed and on the right path to a strong brand. However, if the responses are not consistent across the "brand meaning" level of the CBBE model, or are not consistent across markets (for example if one market's responses are mainly Judgments and another market's responses are mainly Performance) then the brand meaning may be underdeveloped or inconsistently developed among markets. The overall brand meaning response conclusions should be reported by frequency of responses falling into each of the six factors of the CBBE model. After the frequencies of responses are assigned for each stakeholder market, comparisons can be made to ensure proper brand meaning development between stakeholder markets.

Brand identity was skipped over in this process due to the broad generalizations in the "categorical identification" of a brand associated with the brand identity factor of the CBBE model. More than likely, an engineering department will at least be recognized as an engineering discipline, and a business program will be recognized as a business discipline, the appropriate brand identity for each. Brand meaning was evaluated as the next step in the CBBE model to ensure a strong brand.

The next step in the analysis is whether the responses between the stakeholder groups or markets are similar. For this part of the analysis, responses within each factor of the CBBE model are coded and compared for common themes. Similarities between the markets' responses indicate a consistency that supports the student to industry process. Inconsistencies between the markets or with the academic department's desired brand meaning spell trouble for the department and strongly suggest the need for intense marketing of the brand. Software packages such as Megaputer's Polyanalyst and NVIVO can aid greatly in the process of data mining text responses for similarities and trends. Data mining open ended qualitative questions will aid in the evaluation of the actual brand meaning between two markets and also allow an organization to compare that brand meaning to what they ultimately desire their markets to have.

\section{SYSTEMATIC PROCESS FOR EVALUATING AN ACADEMIC DEPARTMENT'S BRAND MEANING APPLIED TO A CASE STUDY: DEPARTMENT OF ENGINEERING MANAGEMENT AND SYSTEMS ENGINEERING}

The Department of Engineering Management and Systems Engineering at Missouri S\&T was chosen as a department to evaluate its brand meaning due to anecdotal evidence suggesting the department is misunderstood on the Missouri S\&T campus by fellow students and faculty, and in the overall field of engineering. The goal of the analysis was to better understand how the brand meaning of engineering management is perceived by potential students and employers so as to improve the cyclical process of student throughput to industry jobs.

Since the goal of this study was to evaluate the cyclical process of recruiting students and hiring of graduates by industry and to determine the alignment of the understanding of engineering management between both markets, a population of respondents from industry and academia was recruited to participate in this study. Respondents were obtained from Rolla High School, a local high school in the same town as the Department of Engineering Management and Systems Engineering, in order to gain insight of the potential incoming student population's understanding of Engineering Management. A total of 56 respondents were obtained from this "expert" group to evaluate what the understanding of engineering management is and what brand meaning exists for the industrial stakeholder market. This industrial stakeholder market was also asked to report what the engineering management brand meaning should be. Thirty three of these expert respondents were from an academic setting, while 23 were from industrial companies such as Anheuser-Busch ${ }^{\mathrm{TM}}$, Ford Motor Company ${ }^{\mathrm{TM}}$, Boeing ${ }^{\mathrm{TM}}$ and John Deere $^{\mathrm{TM}}$. Responses from academic settings included Missouri S\&T, University of Colorado - Boulder, University of the Pacific, University of Tennessee - Chattanooga, and Stevens Institute of Technology. Missouri S\&T and 
Stevens Institute of Technology were chosen as target programs due to their ABET accreditation and degree offerings from Bachelor of Science through Doctor of Philosophy (http://emgt.umr.edu/department/deptprofile.html, 2007; (http://www.stevens.edu/ses/seem/About_SEEM/management.html, 2007). The University of Colorado Boulder and the University of Tennessee - Chattanooga were both chosen as representation of schools offering Master level degrees in Engineering Management (http://emp.colorado.edu/,2008; and http://www.utc.edu/Departments/engrcs/engm/index.php, 2008). The University of the Pacific was chosen due to its undergraduate program that was recently ABET accredited. Again, this population was surveyed to obtain perceptions and understanding of professionals that could potentially be employers of engineering management graduates, both in academia and industrial companies. See Table 1 for a summary of respondent demographics. Gender differences were not deemed a value added demographic to the study and therefore were not recorded.

Table 1: Population Demographic Summary

\begin{tabular}{|l|c|c|c|}
\hline \multicolumn{1}{|c|}{ Population } & N & Male & Female \\
\hline RHS & 118 & 66 & 52 \\
\hline Missouri S\&T Freshmen & 705 & 579 & 126 \\
\hline Missouri S\&T EMGP Upperclassmen & 116 & 84 & 32 \\
\hline Industry & 23 & NA & NA \\
\hline Academia & 33 & NA & NA \\
\hline
\end{tabular}

Results of Case Study. Table 2 summarizes the finding of overall self-reported understanding of engineering for each population group. Note that the $\mathrm{N}$ reported in the following table represents the valid $\mathrm{N}$ for the self-reported data because each respondent may have not given a response to each item in the survey questionnaire.

Table 2: Summary Of Mean Responses To Overall Understanding Of Engineering

\begin{tabular}{|l|c|c|c|c|c|c|c|c|}
\hline & $\mathbf{N}$ & Mean & $\begin{array}{c}\text { Std. } \\
\text { Deviation }\end{array}$ & $\begin{array}{c}\text { Std. } \\
\text { Error }\end{array}$ & $\begin{array}{c}\text { 95\% Confidence Interval } \\
\text { for Mean }\end{array}$ & Minimum & Maximum \\
\hline & & & & & $\begin{array}{c}\text { Lower } \\
\text { Bound }\end{array}$ & $\begin{array}{c}\text { Upper } \\
\text { Bound }\end{array}$ & \\
\hline RHS & 117 & 2.534 & .890 & .082 & 2.371 & 2.697 & 1.00 & 5.00 \\
\hline MISSOURI S\&T Freshmen & 699 & 3.291 & .715 & .027 & 3.238 & 3.344 & 1.00 & 5.00 \\
\hline $\begin{array}{l}\text { MISSOURI S\&T EMGT } \\
\text { Upperclassmen }\end{array}$ & 117 & 3.586 & .720 & .067 & 3.453 & 3.717 & 1.00 & 5.00 \\
\hline Total & 933 & 3.233 & .791 & .026 & 3.182 & 3.284 & 1.00 & 5.00 \\
\hline
\end{tabular}

Data were collected regarding overall self-reported levels of understanding of engineering as a field. This serves as a baseline of understanding to compare self-reported levels of understanding by specific disciplines. Table 2 and Figure 5 display the increase in engineering as a whole from high school students through upperclassmen at Missouri S\&T. This increase in understanding was expected due to the natural phenomenon of increase in knowledge with time and familiarity. Therefore, it would be expected that the upperclassmen engineering students have higher self-reported knowledge of engineering than high school students. 


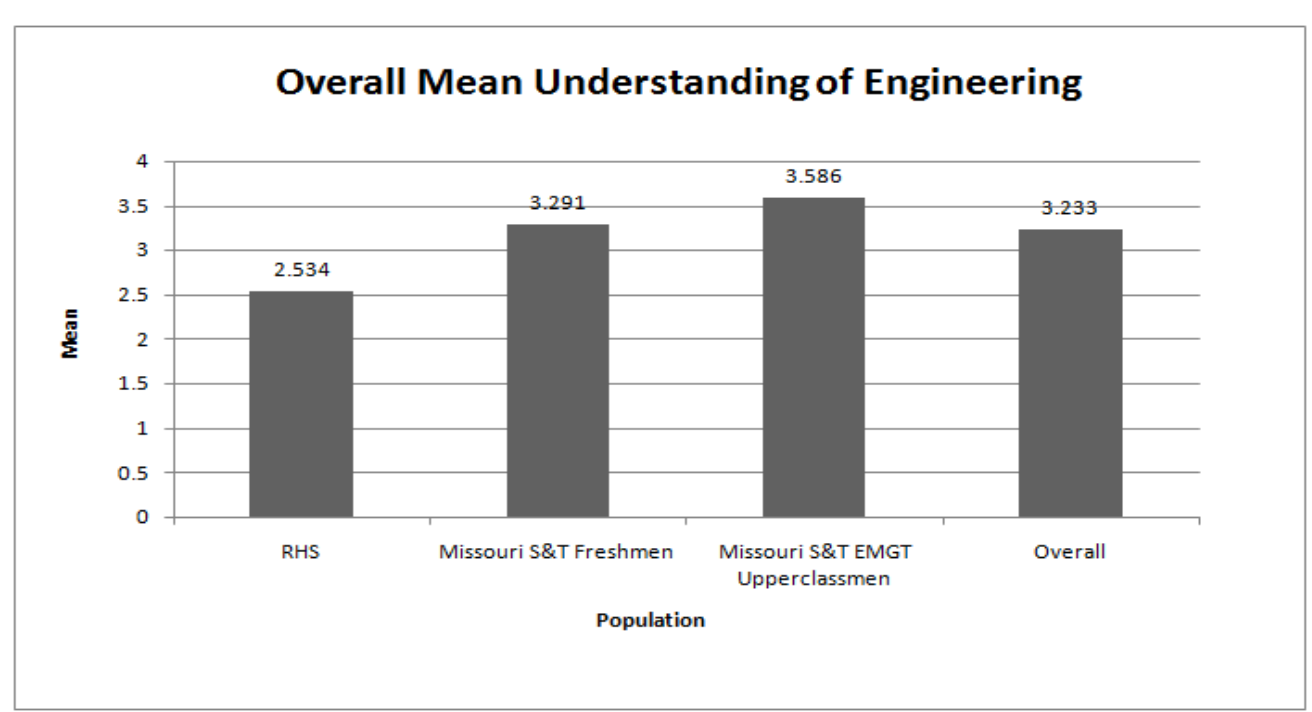

Figure 5: Mean Understanding Of Engineering

In order to ensure a statistically significant difference in means, an ANOVA was performed. Table 3 shows the results from an ANOVA analysis of variance conducted between the self-reported response means for the RHS, Missouri S\&T freshmen, and Missouri S\&T engineering management upperclassmen populations. The ANOVA test is used to test the hypothesis that means are equal, and then disprove that hypothesis if means differ from one another. There is a significant difference of means between the three student populations, indicated by an F value of 67.632 at the $\alpha=.05$ significance level (see Table 3 ).

Table 3: ANOVA for Overall Understanding Of Engineering

\begin{tabular}{|l|c|c|c|c|c|}
\hline & Sum of Squares & df & Mean Square & F & Sig. \\
\hline Between Groups & 74.033 & 2 & 37.017 & 67.632 & .000 \\
\hline Within Groups & 509.014 & 930 & .547 & & \\
\hline Total & 583.047 & 932 & & & \\
\hline
\end{tabular}

Table 4: Tukey Post Hoc For Overall Understanding of Engineering

\begin{tabular}{|c|c|c|c|c|c|c|}
\hline $\begin{array}{l}\text { (I) Population } \\
\text { Code }\end{array}$ & $\begin{array}{c}\text { (J) Population } \\
\text { Code }\end{array}$ & $\begin{array}{c}\text { Mean Difference } \\
\text { (I-J) }\end{array}$ & Std. Error & Sig. & \multicolumn{2}{|c|}{ 95\% Confidence Interval } \\
\hline & & & & & Lower Bound & Upper Bound \\
\hline $\begin{array}{l}\text { Missouri S\&T } \\
\text { Freshmen }\end{array}$ & RHS & $.757(*)$ & .074 & .000 & .584 & .930 \\
\hline \multirow{3}{*}{ RHS } & $\begin{array}{l}\text { Missouri S\&T } \\
\text { EMGT } \\
\text { Upperclassmen }\end{array}$ & $-.294(*)$ & .074 & .000 & -.468 & -.121 \\
\hline & $\begin{array}{l}\text { Missouri S\&T } \\
\text { Freshmen }\end{array}$ & $-.757(*)$ & .074 & .000 & -.930 & -.584 \\
\hline & $\begin{array}{l}\text { Missouri S\&T } \\
\text { EMGT } \\
\text { Upperclassmen }\end{array}$ & $-1.051(*)$ & .097 & .000 & -1.278 & -.824 \\
\hline \multirow{2}{*}{$\begin{array}{l}\text { Missouri S\&T } \\
\text { EMGT } \\
\text { Upperclassmen }\end{array}$} & Missouri S\&T & $.294(*)$ & .074 & .000 & .121 & .468 \\
\hline & RHS & $1.051(*)$ & .097 & .000 & .824 & 1.278 \\
\hline
\end{tabular}

* The mean difference is significant at the .05 level. 
Table 4 represents the Post Hoc Tukey values for the difference in means for each of the student populations. There is a significant difference in means for each comparison combination for the three student populations ranging from .294 to 1.051 at the $\alpha=0.05$ significance level.

Table 5 also displays results from the Tukey Post Hoc test ensuring that none of the means for each student population group are the same, hence no two means being present in the same column. For example, the RHS mean of 2.534 is displayed in column one, with no other mean from any other student population also being displayed in column one, thereby indicating that no other population mean is equal to the RHS mean.

Table 5: Tukey Post Hoc Comparison Of Means For Overall Understanding Of Engineering

\begin{tabular}{|l|c|c|c|c|}
\hline \multirow{2}{*}{ Population Code } & \multirow{2}{*}{$\mathbf{N}$} & \multicolumn{3}{c|}{ Subset for alpha.$- \mathbf{0 5}$} \\
\cline { 3 - 5 } & 117 & 2.534 & $\mathbf{2}$ & $\mathbf{3}$ \\
\hline RHS & 699 & & 3.291 & \\
\hline Missouri S\&T Freshmen & 117 & & & 3.586 \\
\hline Missouri SUT EMGT Upperclassmen & & & & \\
\hline
\end{tabular}

Table 6 shows the rankings of each of the sixteen engineering disciplines at Missouri S\&T for each group of the student population. This table also shows an increasing trend in the understanding of the engineering management field specifically through the academic timeframe for a student. The self-reported mean understanding for engineering management for RHS students $(\mu=1.62)$ was lower than the self-reported mean understanding for Missouri $S \& T$ freshmen $(\mu=2.54)$. Intuitively, the self-reported mean understanding of engineering management by engineering management upperclassmen should be, as is the case, the highest mean of 4.23. Engineering management was ranked twelfth out of sixteen in self-reported understanding of the engineering disciplines at Missouri S\&T by the Rolla High School students while the Missouri S\&T freshman ranked it eighth out of sixteen. Expectedly, the engineering management upperclassmen ranked engineering management first out of sixteen based on self-reported understanding.

Table 6: Ranked Understanding Of Engineering Disciplines At Missouri S\&T (Mean)

\begin{tabular}{|c|c|c|c|}
\hline Ranking & Rolla High School (N=118) & Missouri S\&T Freshmen (N-704) & $\begin{array}{c}\text { Missouri S\&T EMGT } \\
\text { Upperclassmen (N-117) }\end{array}$ \\
\hline 1 & Architectural Engineering (2.34) & Mechanical Engineering (3.37) & Engineering Management (4.23) \\
\hline 2 & Mechanical Engineering (2.26) & Civil Engineering (3.18) & Civil Engineering (3.25) \\
\hline 3 & Computer Engineering (2.16) & Electrical Engineering (2.84) & Mechanical Engineering (3.21) \\
\hline 4 & Aerospace Engineering (2.14) & Architectural Engineering (2.83) & Electrical Engineering (2.81) \\
\hline 5 & Electrical Engineering (2.10) & Aerospace Engineering (2.76) & Interdisciplinary Engineering (2.76) \\
\hline 6 & Civil Engineering (2.08) & Computer Engineering (2.64) & Computer Engineering (2.69) \\
\hline 7 & Chemical Engineering (2.04) & Chemical Engineering (2.60) & Architectural Engineering (2.64) \\
\hline 8 & Mining Engineering (1.92) & Engineering Management (2.54) & Chemical Engineering (2.40) \\
\hline 9 & Nuclear Engineering (1.85) & Nuclear Engineering (2.38) & Aerospace Engineering (2.32) \\
\hline 10 & Environmental Engineering (1.80) & Metallurgical Engineering (2.34) & Metallurgical Engineering (2.17) \\
\hline 11 & Geological Engineering (1.79) & Mining Engineering (2.31) & Environmental Engineering (2.08) \\
\hline 12 & Engineering Management (1.62) & Petroleum Engineering (2.20) & Mining Engineering (2.04) \\
\hline 13 & Ceramic Engineering (1.61) & Interdisciplinary Engineering (2.17) & Nuclear Engineering (2.03) \\
\hline 14 & Metallurgical Engineering (1.55) & Environmental Engineering (2.11) & Petroleum Engineering (2.02) \\
\hline 15 & Petroleum Engineering (1.51) & Ceramic Engineering (2.11) & Ceramic Engineering (2.00) \\
\hline 16 & Interdisciplinary Engineering (1.29) & Geological Engineering (2.04) & Geological Engineering (1.96) \\
\hline
\end{tabular}

Table 7 show trends in the understanding of each of the sixteen engineering disciplines offered at Missouri S\&T by all academic stages of the student population. This data demonstrate a critical lack of student understanding of engineering at the high school level; this may impact early college career planning. 
Table 7: Overall Mean Understanding Of Engineering Disciplines At Missouri S\&T

\begin{tabular}{|l|c|c|c|}
\hline $\begin{array}{c}\text { Discipline on Missouri S\&T } \\
\text { Campus }\end{array}$ & $\begin{array}{c}\text { Rolla High School } \\
(\mathbf{N = 1 1 8})\end{array}$ & $\begin{array}{c}\text { Missouri S\&T Freshmen } \\
(\mathbf{N = 7 0 4 )}\end{array}$ & $\begin{array}{c}\text { Missouri S\&T EMGT } \\
\text { Upperclassmen (N-117) }\end{array}$ \\
\hline Aerospace Engineering & 2.14 & 2.76 & 2.32 \\
\hline Architectural Engineering & 2.34 & 2.84 & 2.64 \\
\hline Ceramic Engineering & 1.61 & 2.11 & 2.00 \\
\hline Chemical Engineering & 2.04 & 2.60 & 2.40 \\
\hline Civil Engineering & 2.08 & 3.18 & 3.26 \\
\hline Computer Engineering & 2.16 & 2.64 & 2.69 \\
\hline Electrical Engineering & 2.10 & 2.84 & 2.81 \\
\hline Engineering Management & 1.62 & 2.54 & 4.23 \\
\hline Environmental Engineering & 1.80 & 2.11 & 2.08 \\
\hline Geological Engineering & 1.79 & 2.04 & 1.96 \\
\hline Interdisciplinary Engineering & 1.29 & 2.17 & 3.21 \\
\hline Mechanical Engineering & 2.26 & 3.37 & 2.17 \\
\hline Metallurgical Engineering & 1.55 & 2.34 & 2.04 \\
\hline Mining Engineering & 1.92 & 2.31 & 2.03 \\
\hline Nuclear Engineering & 1.85 & 2.38 & 2.03 \\
\hline Petroleum Engineering & 1.51 & 2.17 & 2.76 \\
\hline
\end{tabular}

After the establishment of a significant difference in the mean level of understanding of engineering in general, the next step was to determine if there is a significant difference in mean self-reported differences in understanding of engineering management specifically by the population. Table 8 shows the demographics for each student population and their overall self-reported mean understanding of engineering management.

Table 8: Descriptive Statistics For Understanding Of Engineering Management

\begin{tabular}{|l|c|c|c|c|c|c|c|c|}
\hline & $\mathbf{N}$ & Mean & $\begin{array}{c}\text { Std. } \\
\text { Deviation }\end{array}$ & $\begin{array}{c}\text { Std. } \\
\text { Error }\end{array}$ & \multicolumn{2}{|c|}{$\mathbf{9 5 \% \text { Confidence }}$} & Minimum & Maximum \\
\hline & & & & & $\begin{array}{c}\text { Lower } \\
\text { Bound }\end{array}$ & $\begin{array}{c}\text { Upper } \\
\text { Bound }\end{array}$ & & \\
\hline RHS & 118 & 1.617 & .773 & .071 & 1.478 & 1.760 & 1.00 & 5.00 \\
\hline Missouri S\&T Freshmen & 704 & 2.542 & 1.101 & .042 & 2.460 & $2 . .623$ & 1.00 & 5.00 \\
\hline $\begin{array}{l}\text { Missouri S\&T EMGT } \\
\text { Upperclassmen }\end{array}$ & 117 & 4.231 & .923 & .085 & 4.062 & 4.400 & 1.00 & 5.00 \\
\hline Total & 939 & 2.636 & 1.242 & .041 & 2.557 & 2.716 & 1.00 & 5.00 \\
\hline
\end{tabular}

* The mean difference is significant at the .05 level.

An ANOVA analysis of variance was also conducted to test whether or not the means of the three student populations were the same regarding their self-reported understanding of engineering management. An F statistic of 195.212 shows a statistically significant difference of means at the $\alpha=.05$ significance level (see Table 9).

Table 9: ANOVA For Understanding Of Engineering Management

\begin{tabular}{|l|c|c|c|c|c|}
\hline & Sum of Squares & df & Mean Square & F & Sig. \\
\hline Between Groups & 425.930 & 2 & 212.965 & 195.212 & .000 \\
\hline Within Groups & 1021.122 & 936 & 1.091 & & \\
\hline Total & 1447.052 & 938 & & & \\
\hline
\end{tabular}

Tukey's Post Hoc test revealed a statistically significant difference in means between all comparison combinations between the three groups with mean differences ranging from .923 to 2.612 at the $\alpha=.05$ level (See Table 10). Table 10 (Tukey Post Hoc) shows a statistically significant difference between the means of the three student populations because no two means reside in the same column. 
Table 10: Tukey Post Hoc For Understanding Of Engineering Management

\begin{tabular}{|c|c|c|c|c|c|c|}
\hline \multirow[t]{2}{*}{$\begin{array}{c}\text { (I) Population } \\
\text { Code }\end{array}$} & \multirow[t]{2}{*}{$\begin{array}{c}\text { (J) Population } \\
\text { Code }\end{array}$} & \multirow[t]{2}{*}{$\begin{array}{l}\text { Mean Difference } \\
\text { (I-J) }\end{array}$} & \multirow[t]{2}{*}{ Std. Error } & \multirow[t]{2}{*}{ Sig. } & \multicolumn{2}{|c|}{$\mathbf{9 5 \%}$ Confidence Interval } \\
\hline & & & & & Lower Bound & Upper Bound \\
\hline \multirow[b]{2}{*}{$\begin{array}{l}\text { Missouri S\&T } \\
\text { Freshmen }\end{array}$} & RHS & $.923(*)$ & .104 & .000 & .675 & 1.167 \\
\hline & $\begin{array}{l}\text { Missouri S\&T } \\
\text { EMGT } \\
\text { Upperclassmen }\end{array}$ & $-1.689(*)$ & .104 & .000 & -1.934 & -1.444 \\
\hline \multirow[t]{2}{*}{ RHS } & $\begin{array}{l}\text { Missouri S\&T } \\
\text { Freshmen }\end{array}$ & $-.923(*)$ & .104 & .000 & -1.167 & -.679 \\
\hline & $\begin{array}{l}\text { Missouri S\&T } \\
\text { EMGT } \\
\text { Upperclassmen }\end{array}$ & $-2.612(*)$ & .136 & .000 & -2.932 & -2.292 \\
\hline \multirow{2}{*}{$\begin{array}{l}\text { Missouri S\&T } \\
\text { EMGT } \\
\text { Upperclassmen }\end{array}$} & $\begin{array}{l}\text { Missouri S\&T } \\
\text { Freshmen }\end{array}$ & $1.689(*)$ & .104 & .000 & 1.444 & 1.934 \\
\hline & RHS & $2.612(*)$ & .136 & .000 & 2.292 & 2.932 \\
\hline
\end{tabular}

* The mean difference is significant at the .05 level.

Table 11: Tukey Post Hoc Comparison Of Means For Understanding Engineering Management

\begin{tabular}{|c|c|c|c|c|}
\hline \multicolumn{5}{|c|}{ T } \\
\hline \multirow[b]{2}{*}{ Population Code } & \multirow[t]{2}{*}{$\mathbf{N}$} & \multicolumn{3}{|c|}{ Subset for alpha -.05} \\
\hline & & 1 & 2 & 3 \\
\hline RHS & 118 & 1.619 & & \\
\hline Missouri S\&T Freshmen & 704 & & 2.542 & \\
\hline Missouri SUT EMGT Upperclassmen & 117 & & & 4.231 \\
\hline
\end{tabular}

Frequencies of responses for each of the categories of the Customer Based Brand Equity Model (CBBE) were calculated and are displayed in Table 12 and Figure 6. Note that not all students in the population for each group responded to all questions on the survey instrument. For example, even though there were 705 Missouri S\&T freshmen in the population, to minimize the completion time of the survey instrument each respondent was asked to respond to only a subset of the branding questions for the sixteen engineering disciplines at Missouri S\&T. The surveys containing subsets of questions were distributed randomly, and as evenly as possible to prevent data skewing. Only 189 valid responses were obtained to the engineering management branding question from the Missouri S\&T freshmen population because of limited time allotted to the respondents to complete the survey. The frequencies of brand meaning responses were coded and analyzed at all population groups, including industry, to shed light about the congruency of brand meaning between students and potential employers.

Table 12: Brand Meaning Responses To EMGT Via CBBE Model

\begin{tabular}{|l|c|c|c|c|c|c|c|}
\hline & & \multicolumn{5}{|c|}{ Percent Response } \\
\hline Population & $\mathbf{N}$ & Salience & Performance & Imagery & Judgments & Feelings & Resonance \\
\hline RHS & 50 & $3.4 \%$ & $62.1 \%$ & $13.8 \%$ & $0.0 \%$ & $6.9 \%$ & $0.0 \%$ \\
\hline Missouri S\&T Freshmen & 189 & $16.6 \%$ & $67.4 \%$ & $3.1 \%$ & $1.6 \%$ & $8.8 \%$ & $0.5 \%$ \\
\hline $\begin{array}{l}\text { Missouri S\&T EMGT } \\
\text { Upperclassmen }\end{array}$ & 135 & $18.2 \%$ & $54.7 \%$ & $4.4 \%$ & $2.9 \%$ & $18.2 \%$ & $0.0 \%$ \\
\hline Industry & 23 & $43.5 \%$ & $21.7 \%$ & $4.3 \%$ & $30.4 \%$ & $0.0 \%$ & $0.0 \%$ \\
\hline Academia & 35 & $31.4 \%$ & $37.1 \%$ & $0.0 \%$ & $28.6 \%$ & $0.0 \%$ & $2.9 \%$ \\
\hline Overall Student \& Industry & 433 & $17.9 \%$ & $57.9 \%$ & $4.7 \%$ & $5.6 \%$ & $10.3 \%$ & $0.4 \%$ \\
\hline Industry-Desired Response & 23 & $43.5 \%$ & $8.7 \%$ & $010 \%$ & $47.8 \%$ & $0.0 \%$ & $0.0 \%$ \\
\hline Academia-Desired Response & 33 & $21.2 \%$ & $30.3 \%$ & $6.1 \%$ & $39.4 \%$ & $0.0 \%$ & $2.9 \%$ \\
\hline
\end{tabular}




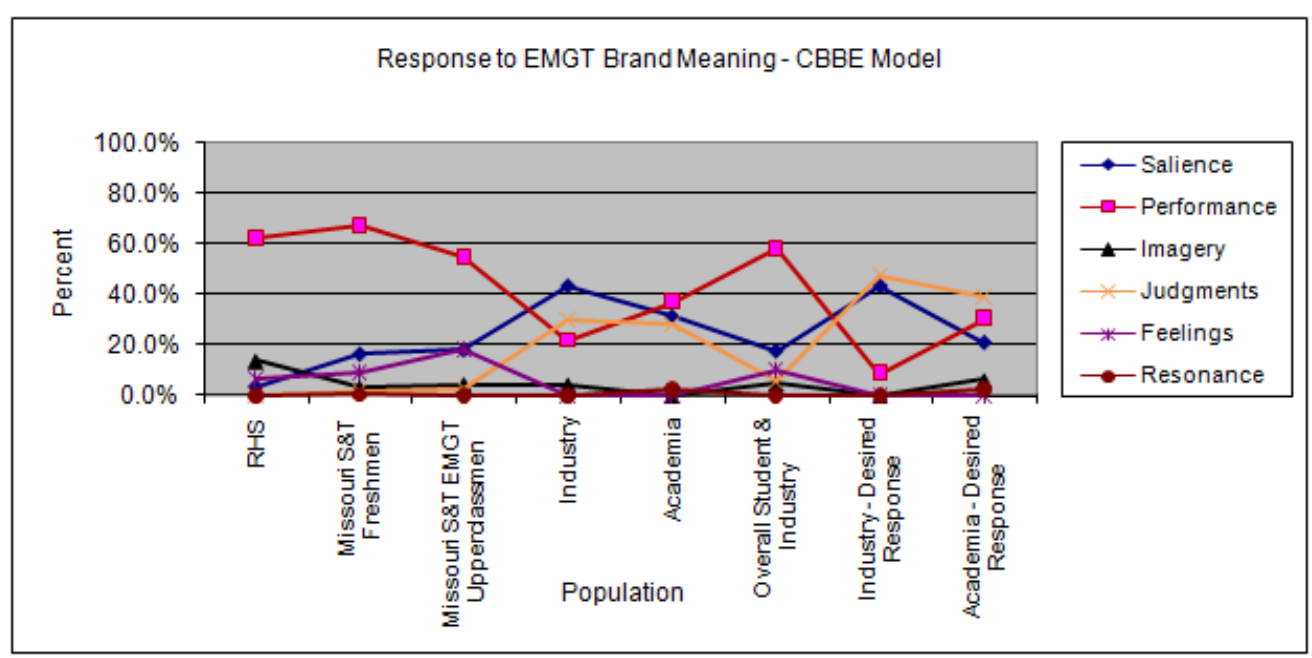

Figure 6: Brand Meaning Responses To EMGT Via CBBE Model

The survey instrument item which the population members were asked to respond to was a word associations question aimed at assessing "brand meaning." According to the CBBE Model (Noeth, 2003), responses to brand meaning should fall into either the Performance or Imagery categories to be considered an "appropriate" response to brand meaning. Responses that fall into the other four categories were considered inappropriate for measuring brand meaning since the respondent was specifically asked a question pertaining to brand meaning. If the response did not align with the categories that make up brand meaning (Imagery and Performance) then the respondent's brand meaning is referring to another level of the CBBE model and is not aligned with creating a strong brand.

Performance responses included responses regarding specific job functions of engineering management graduates such as "supervising," "manager," and "paperpusher." Missouri S\&T freshmen give the most responses to brand meaning using a term that falls into the Performance factor (67.4\%). Responses falling into the Imagery factor, the other factor appropriate for measuring brand meaning, are not as frequently reported, however (RHS population reported an Imagery Response $13.8 \%$ of the time). This means that most of the responses to brand meaning were something other than those relative to brand meaning, thereby creating a disjoint in the alignment of the establishment of an ideal brand as outlined by the CBBE Model and reality for engineering management. This misalignment could prove harmful to engineering management's efforts to recruit student and then place them in industry.

In order to specifically analyze the alignment of market brand response between students and potential employers, the student population responses was compared with that of the academic and industry responses. Analysis of these responses is outlined in Tables 13 and 14.

Table 13: Brand Meaning Responses Per CBBE Model

\begin{tabular}{|l|c|c|c|c|}
\hline \multicolumn{1}{|c|}{ Population } & Brand Identity & Brand Meaning & Brand Response & Brand Relationship \\
\hline RHS & $3.4 \%$ & $75.9 \%$ & $6.9 \%$ & $0.0 \%$ \\
\hline Missouri S\&T Freshmen & $16.6 \%$ & $70.5 \%$ & $10.4 \%$ & $0.5 \%$ \\
\hline Missouri S\&T EMGT Upperclassmen & $18.2 \%$ & $59.1 \%$ & $21.1 \%$ & $0.0 \%$ \\
\hline Industry & $43.5 \%$ & $26.0 \%$ & $30.4 \%$ & $0.0 \%$ \\
\hline Academia & $31.4 \%$ & $37.1 \%$ & $28.6 \%$ & $2.9 \%$ \\
\hline Overall Student \& Industry & $17.9 \%$ & $62.6 \%$ & $15.9^{\wedge}$ & $0.4 \%$ \\
\hline Industry-Desired Response & $43.5 \%$ & $8.7 \%$ & $47.8 \%$ & $0.0 \%$ \\
\hline Academia-Desired Response & $21.2 \%$ & $36.4 \%$ & $39.4 \%$ & $2.9 \%$ \\
\hline
\end{tabular}


Table 14: Brand Meaning Responses Appropriateness And Implications

\begin{tabular}{|l|c|c|}
\hline \multicolumn{1}{|c|}{ Population } & Majority Response to Brand Meaning Question & Implications \\
\hline RHS & Brand Meaning & Appropriate \\
\hline Missouri S\&T Freshmen & Brand Meaning & Appropriate \\
\hline Missouri S\&T EMGT Upperclassmen & Brand Meaning & Appropriate \\
\hline Industry & Brand Identity & Inappropriate \\
\hline Academia & Brand Meaning & Appropriate \\
\hline Overall Student \& Industry & Brand Meaning & Appropriate \\
\hline Industry-Desired Response & Brand Response & Inappropriate \\
\hline Academia-Desired Response & Brand Response & Inappropriate \\
\hline
\end{tabular}

The majority of the responses from the student and from the academic populations fall into the brand meaning category of the CBBE model. The academic stakeholder population yielded $37.1 \%$, while the student populations yielded $75.9 \%$ for RHS, $70.5 \%$ for Missouri S\&T freshmen, and $59.1 \%$ for Missouri S\&T upperclassmen. While the brand meaning responses for this population are considered appropriate, the responses are not aligned with the industry stakeholder brand meaning responses. These responses are indicative of a brand identity response (See Table 13), thereby making the industry population responses inappropriate responses to brand meaning. Brand identity responses such as "business," "management," or "engineering" reflect a broad base of how engineering management fundamentally is seen. This response indicates that industrial professionals respond to engineering management's brand meaning as a difference of fields of practice or study, whereas the student and academic stakeholder populations respond to engineering management's brand meaning as a matter of specific job function of graduates. This difference of the brand meaning to each of the stakeholder populations can be detrimental in the cyclical student recruitment to employer hiring process due to the misalignment across the student and potential employer market and within the potential employer population itself. Since the department name is merely a descriptor of the brand, and it does not include other fundamental components of a brand such as a logo or slogan, it is not terribly surprising that, as shown in Table 12, the industry responses are more relevant to Salience (Brand Identity) than to Performance or Imagery (brand meaning). Also, note that a significant portion of the academia responses were also related to Salience (brand identity). Future research could be of value to study the brand responses if the department developed more components of a traditional brand such as a slogan or logo.

The potential employer population was also asked to give responses as to what they would like for engineering management's brand meaning to be ("desired responses" as shown in Table 12 and 13). The majority of the responses for the academic portion of this stakeholder group fell into the Judgments category (brand response) making their responses inappropriate for desired brand meaning per the CBBE model. The industry portion of this stakeholder group also responded with a majority falling into the Judgments category (brand response), making their responses to desired brand meaning inappropriate (See Table 14).

The desired responses for both the academic and industrial stakeholder groups were inappropriate, falling to the brand response category of the CBBE model. This response is categoristic of questions like "how do I feel about you?" with a Judgement or Feeling. Academia and industrial stakeholders have responded that they wish for the brand to be viewed in a Judgment or Feeling response. It is not surprising that academic stakeholders wish for their department or degree to be viewed as valuable (Judgment) or be liked (Feeling). Industrial stakeholders would also like the same response to the department since they have hired or may consider hiring graduates. Actual responses from the academic stakeholder group showed that they responded with a Performance majority. This is not surprising, since the academic stakeholder group is very familiar with the actual functions of the department. The actual responses from the industrial stakeholder group were a majority of Salience responses. Fundamentally, industry is making their response based on "what are you" type questions. In the case of Engineering Management, industry is determining whether or not the department is an engineering or perhaps business/management department, which is critical when making hiring decisions.

\section{CONCLUSIONS}

This study shows the development and application of a process for evaluating an academic department's brand meaning among different markets. It is novel in that it shows academic departments a path to take in 
determining perception problems by using a systematic approach developed from Keller's Customer Based Brand Equity model to evaluate brand meaning. It is expected that this model may be useful for applications to a whole university and outside academia.

Comprehension levels regarding engineering management and the 15 other departments that reside in the overall engineering field have been gathered and reported. Engineering management ranked behind other departments at Missouri S\&T, identifying a potential point of marketing improvements. Since the understanding and brand response of engineering management is misaligned, there is a potential barrier for student recruitment to the field of engineering and employment.

According to the CBBE model, the hierarchical steps of building a strong brand must be followed to reach high brand resonance with its respondents. In this case, the results of brand meaning suggests that establishing an appropriate brand response and ultimately brand resonance between stakeholder groups will be difficult since a sound brand meaning is crucial to establishing brand response and brand resonance (Keller, 2001). The results suggest that an appropriate brand meaning across stakeholder markets needs to be established before engineering management can move up the hierarchical pyramid of the CBBE model and become a strong brand.

Overall, this model helps an academic department that is trying to serve more than one market evaluate its brand meaning by eliciting brand meaning from each market via word association. This process serves as a means to ensure that all stakeholder groups are responding with a brand meaning response in general If all markets respond with a brand meaning response, then the academic department is getting closer to aligning the perceptions of the markets relative to brand meaning. Once the markets show alignment in response to the brand meaning question, then the forms of the brand meaning response can be compared between groups and with the desired brand meaning.

This information can be useful in aiding recruitment efforts of departments. Frequently, individual departments do not have resources to put substantial efforts into recruiting on their own and rely on the University at which they are located to perform recruitment tasks. If the department itself understood its stakeholder groups and their perceptions of their department, they could more efficiently perform recruiting efforts on their own. They would understand which stakeholder groups needed more effort to improve recruiting for both new students and industrial companies to hire their graduates.

\section{AUTHOR INFORMATION}

Cassandra Elrod is an Assistant Professor of Operations Management in the Department of Business \& Information Technology at the Missouri University of Science \& Technology (email: cassa@ mst.edu). She received her Ph.D. from the University of Missouri - Rolla in Engineering Management. She has taught a variety of courses, including marketing, finance, new product development, management and organizational behavior, operations management, decision making, and engineering economics. Her current research interests focus on new product development, quality management, lean and Six Sigma strategies, brand management, project management, operations management, and higher education brand management.

William J. Daughton is a Professor and Chair of the Engineering Management and Systems Engineering (EMSE) Department at the Missouri University of Science and Technology. He also has over 15 years of experience in technical and business unit management in the semiconductor industry at Texas Instruments and NCR Microelectronics. Dr. Daughton holds a BS degree from Illinois College, an MS degree from the South Dakota School of Mines and Technology, and a PhD from the University of Missouri - Columbia. Dr. Daughton was recognized by the Engineering Management Division of the ASEE with the Bernard R. Sarchet Award for Lifetime Achievement in Engineering Management Education in 2007. He also serves as the Executive Director of the ASEM and was recognized by ASEM in 2009 for his leadership in the society with its Bernard R. Sarchet Award.

Susan L. Murray, P.E. is an Associate Professor in the Engineering Management and Systems Engineering Department at the Missouri University of Science and Technology (formerly University of Missouri-Rolla). Dr. Murray received her B.S. and Ph.D. in industrial engineering from Texas A\&M University. Her M.S. is also in industrial engineering from the University of Texas-Arlington. She is a professional engineer in Texas. Her research 
and teaching interests include productivity improvement, human performance, safety, project management, and engineering education. Prior to her academic position, she spent seven years working in industry, including two years at NASA's Kennedy Space Center.

Caroline M. Fisher is a Professor and Chair of the Department of Business and Information Technology at the Missouri University of Science and Technology. She joined Missouri S\&T as the Chair of Business Administration and the Associate Dean of the School of Management and Information Systems in August 2005. From August 2006 to August 2007, she served as the Dean of the School of Management and Information Systems. She came to Missouri S\&T from Loyola University New Orleans where she taught since 1985 and held the position of Bank One/Francis C. Doyle Distinguished Professor of Marketing at the College of Business. She served as coordinator of the marketing department, directed Loyola's Six Sigma executive training program, established and ran the Master of Quality Management program from 1993 to 2002, and was the director of the MBA program from 1992 to 1994. Dr. Fisher has taught Customer Focus and Satisfaction, Strategic Quality Management, Statistics, Statistical Process Control, Design of Experiments, Quality Function Deployment, Consumer Analysis and Research, Promotions Management, and E-commerce. She conducts research in the theory of quality management and in customer satisfaction and loyalty.

Barry B. Flachsbart is a Professor of Information Science and Technology in the Business and Information Technology Department at the Missouri University of Science and Technology. Dr. Flachsbart received his B.S. from St. Louis University and his M.S. and Ph.D. from Stanford University. His research interests include project management, manufacturing systems, large databases, and artificial intelligence. Prior to his academic position, he spent 35 years in industry, including a period as a Director in a Marketing organization and a later period as Director of an Applied Mathematics and Computer Science Research Laboratory.

\section{REFERENCES}

1. $\quad$ Argenti, P. (2000). "Branding B-Schools: Reputation Managemnt for MBA Programs." Corporate Reputation Review: 3 (2).

2. Belk, R. (2006). Handbook of Qualitative Research Methods in Marketing, Edward Elgar Publishing.

3. $\quad$ Bodoh, J. N., Lloyd (2004). Brand Building on the Curriculum. Design Week: 9.

4. Chandon, P. (2003). Note on Measuring Brand Awareness, Brand Image, Brand Equity and Brand Value. Insead Faculty \& Research Working Paper Series.

5. $\quad$ Colyer, E. (2005). Assigned Reading: Branding Gets Credit at University. BrandHome.

6. Conway, T., Mackay, S., and Yorke, D. (1994). Strategic Planning in Higher Education: Who are the Customers? The International Journal of Educational Management 51(6): 29-36.

7. Creswell, J. W. (2005). Educational Research: Planning, Conducting and Evaluating Quantitative and Qualitative Research. Columbus, Pearson Merrill Prentice Hall.

8. Elrod, C., C. (2007). The Development and Application of a Systematic Approach to Evaluating and Academic Department's Brand Meaning. Engineering Management \& Systems Engineering. Rolla, MO, University of Missouri - Rolla. PhD: 87.

9. Elrod, C.C., Daughton, W.J., Murray, S.L., and Flachsbart, B.B. (2010). Evaluating the Engineering Management Brand Meaning. Engineering Management Journal 22(2):16-26.

10. Franzak, F., J, \& Cowles, D.L. (1993). Viewing the Curriculum as a Product: Implications from a Marketing Research Study. Journal of Marketing for Higher Education 4(1-2): 143-158.

11. Heist (2007). Reputation Building - Where Do We Begin? http://www.heist.co.uk/corporate identity/120905.cfm?a=a.

12. Hemsley-Brown, J. and Oplatka, I. (2006). Universities in a Competitive Global Marketplace: A Systematic Review of the Literature on Higher Education Marketing. International Journal of Public Sector Management 19(4): 316-338.

13. http://emgt.umr.edu/department/deptprofile.html. cited 2007.

14. http://emp.colorado.edu/. cited 2008 .

15. http://www.stevens.edu/ses/seem/About_SEEM/management.html. cited 2007

16. http://www.utc.edu/Departments/engrcs/engm/index.php. cited 2008 
17. James, D.O. (2006). Extension to Alliance: Aaker and Keller's Model Revisited. Journal of Product \& Brand Management 15(1): 15-22.

18. Judson, K., M., Gorchels, L., and Aurand, T.W. (2006). Building a University Brand from Within: A Comparison of Coaches' Perspectives of Internal Branding. Journal of Marketing for Higher Education 16(1): 97-114.

19. Jung, J. and Sung, E.Y. (2008). Consumer-Based Brand Equity. Journal of Fashion Marketing and Management 12(1): 24-35.

20. Kayaman, R. and Arasli, H. (2007). Customer Based Brand Equity: Evidence From the Hotel Industry. Managing Service Quality. 17(1): 92-109.

21. Keller, K. (1993). Conceptualizing, Measuring, and Managing Customer-Based Brand Equity. Journal of Marketing 57: 1-22.

22. Keller, K. (2001). Building a Customer-Based Brand Equity. Marketing Management 10(July/August): 1519.

23. Keller, K. (2003). Strategic Brand Management: Building, Measuring and Managing Brand Equity. Upper Saddle River, New Jersey, Prentice Hall.

24. Kim, W. G. H. (2004). Measuring Customer-Based Restaurant Brand Equity. Cornell Hotel and Restaurant Administration Quarterly 45(2): 115-131.

25. Kotler, P. (2003). Marketing Management. Upper Saddle River, New Jersey, Prentice Hall.

26. Kuhn, K. F. A. (Retrieved 2007). Applying Keller's Brand Equity Model in a B2B Context: Limitations and an Empirical Test. Griffith University.

27. Kuhn, K.F.A., Alpert, F. and Pope, N.K.L. (2008). An Application of Keller's Brand Equity Model in a B2B Context. Qualitative Market Research: An International Journal 11(1): 40-58.

28. Leitch, A. (May 13, 2005). It's All in Your Head. Folio Focus http://www.ualberta.ca/ pulicas/folio/42/18/focus.html.

29. Marilee's Blog. (2007). http://marilee.vox.com/library/photo/6a00c2251d88c7f21900c2251ed5858fdb.html.

30. Missouri University of Science \& Technology. (2007). Campus picks "S\&T" logo to go with new name. http://news.umr.edu/news/2007/mstlogo.html.

31. Noeth, R.J. (2003). Maintaining a Strong Engineering Workforce. ACT: Iowa City, IA.

32. Petkova, A., Rindova, V., Williamson, I. (2005). Being Good or Being Known: An Emperical Examination of the Dimensions Antecedents, and Consequences of Organizational Reputation. Academy of Management Journal 48(16: 1,022-1,049.

33. Quan, T. H. M. (2006). Retailers' Perceptions of Product Brand Equity: An Empirical Study of Vietnamese Independent Grocers. Economics, Southern Cross University. Master of Arts: 218.

34. Rossum, C. G. B. (2001). Improve Your Marketing Results by Asking Peter F. Drucker's "Five Most Important Questions". Journal of Marketing for Higher Education 10(3): 61-75.

35. Scott, W. A. (1955). Reliability of Content Analysis: The Case of Nominal Scale Coding. Public Opinion Q: 19.

36. Seiver, R., A. (2001). Brand as Relevance. Journal of Marketing for Higher Education 10(3): 77-96.

37. The University of Hawaii System. (2002). Update: Building the University Brand. 1(1).

38. Tong, X. and Hawley, J.M. (2009). Measuring Customer-Based Brand Equity: Empirical Evidence From the Sportswear Market in China. Journal of Product \& Brand Management. 18(4): 262-271.

39. University of New Hampshire. (2007). Branding the University of New Hampshire. http://unh.edu/creative/graphicidentity/.

40. University of Saskatchewan. (2007). Branding the University of Saskatchewan. from http://www.usask.ca/branding.

41. Vidaver-Cohen, D. (2007). Reputation Beyond the Rankings: A Conceptual Framework for Business School Research. Corporate Reputation Review 10 (4).

42. Woods, L. (2000). Brands and Brand Equity: Definition and Management. Management Decision 38(9): 662-669.

43. Young, D. (2007). University Branding Committee. http://www.brandingblog.com/2004/07/university_bran.html. 